\title{
ANALISIS PENGARUH FLEKSIBILITAS DIAFRAGMA TERHADAP DISTRIBUSI HORIZONTAL GAYA GEMPA
}

\author{
Alexander $^{1}$, Daniel Christianto ${ }^{2}$ dan Hadi Pranata ${ }^{3}$

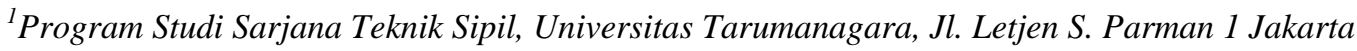 \\ Email: alexander.siauw@gmail.com \\ ${ }^{2}$ Program Studi Sarjana Teknik Sipil, Universitas Tarumanagara, Jl. Letjen S. Parman 1 Jakarta \\ Email:daniel@untar.ac.id \\ ${ }^{3}$ Program Studi Sarjana Teknik Sipil, Universitas Tarumanagara, Jl. Letjen S. Parman 1 Jakarta \\ Email: hp.rematha@gmail.com
}

\begin{abstract}
ABSTRAK
Diafragma adalah elemen struktur yang berfungsi untuk mendistribusi gaya gempa ke elemen vertikal seperti kolom atau dinding geser. Terdapat tiga klasifikasi fleksibilitas diafragma, yaitu diafragma fleksibel, diafragma semi-kaku, dan diafragma kaku. Diafragma pada kajian ini memiliki klasifikasi diafragma fleksibel pada lantai-lantai teratas, sedangkan memiliki klasifikasi diafragma semi-kaku atau diafragma kaku pada lantai-lantai terbawah. Diafragma semi-kaku mensimulasikan perilaku kekakuan sejajar bidang diafragma yang sesungguhnya. Fleksibilitas pada diafragma semi-kaku dapat memengaruhi distribusi horizontal gaya gempa ke elemen vertikal. Semakin kaku diafragma maka gaya gempa akan terdistribusi ke elemen vertikal yang lebih kaku, yaitu dinding geser. Selain itu, ditribusi horizontal gaya gempa juga dipengaruhi oleh koreksi torsi. Terdapat berberapa metode koreksi torsi yang tepat pada diafragma semi-kaku, antara lain metode eksentrisitas statik, metode momen torsi, dan metode koreksi torsi dengan penambahan momen kopel.
\end{abstract}

Kata kunci: fleksibilitas diafragma, distribusi horizontal gaya gempa, pusat kekakuan, eksentrisitas, koreksi torsi diafragma semi-kaku

\section{PENDAHULUAN}

Di dalam peraturan SNI 1726:2012 berisi mengenai ketentuan desain untuk diafragma. Klasifikasi fleksibilitas diafragma berdasarkan SNI 1726:2012 adalah diafragma fleksibel, diafragma semi-kaku, dan diafragma kaku. Dimana untuk asumsi awal desain, diafragma harus dimodelkan sebagai diafragma semi kaku berdasarkan SNI 1726:2012 pasal 7.3.1. Oleh karena itu, perlu diketahui perbedaan hasil distribusi horizontal gaya gempa pada setiap as portal rangka dan dinding geser dengan modifikasi kekakuan diafragma yang berbeda-beda. Selain itu, perlu juga di teliti bagaimana menetapkan metode koreksi torsi yang tepat pada diafragma semi-kaku.

Masih banyak sekali ketidakpastian dalam analisis fleksibilitas diafragma. Oleh karena itu, penulis membatasi diafragma yang di teliti adalah diafragma semi-kaku dengan variasi kekakuan sejajar bidang yang berbeda-beda. Dan dengan variasi tersebut akan diteliti bagaimana perbedaan klasifikasi fleksibilitas diafragma, distribusi horizontal gaya gempa, dan metode koreksi torsi pada diafragma semi-kaku. Hal ini perlu diteliti di Indonesia karena pada selama ini gedung di desain menggunakan diafragma kaku yang mempunyai pengertian diafragma yang mempunyai kekakuan bidang yang tak terbatas sedangkan diafragma semi-kaku adalah diafragma yang mensimulasikan sifat dan perilaku kekakuan bidang sesungguhnya.

Kajian ini dilakukan menggunakan program ETABS (Extended Three Analysis Building Software) yang merupakan sebuah software dalam Teknik Sipil yang dikembangkan oleh CSI (Computer and Structures, inc). Kajian dilakukan dengan studi kasus berdasarkan denah bangunan yang memiliki ketidakberaturan horizontal namun masih diijinkan berdasarkan SNI 1726:2012.

\section{DASAR TEORI}

\section{Klasifikasi fleksibilitas diafragma menurut UBC 1997}

Menurut Uniform Building Code 1997, diafragma fleksibel ketika deformasi diafragma lateral maksimum ( $\Delta$ flexible) lebih dari dua kali simpangan antar lantai tingkat ( $\Delta$ story) (Moeini M.: 2011, 26). Diafragma kaku jika: 


$$
\beta=\frac{\Delta_{\text {flexible }}}{\Delta_{\text {Story }}}<2
$$

Dan diafragma fleksibel, jika:

$$
\beta=\frac{\Delta_{\text {flexible }}}{\Delta_{\text {Story }}} \geq 2
$$

\section{Klasifikasi fleksibilitas diafragma menurut Iran Seismic Code}

Menurut Iran Seismic Code Third Edition, diafragma adalah fleksibel ketika deformasi lateral maksimum diafragma ( $\Delta$ diaph) lebih dari setengah simpangan antar lantai tingkat ( $\Delta$ story) (Moeini M.: 2011, 26). Diafragma adalah kaku ketika:

$$
\lambda=\frac{\Delta_{\text {diaph }}}{\Delta_{\text {Story }}}<0.5
$$

Lalu diafragma adalah fleksibel ketika:

$$
\lambda=\frac{\Delta_{\text {diaph }}}{\Delta_{\text {Story }}} \geq 0.5
$$

Pengertian nilai $\lambda$ dalam Iran Seismic Code, akan mempunyai arti yang sama dengan nilai $\lambda$ pada FEMA 356. Maka dari itu penulis, dalam analisis tidak membandingkan klasifikasi diafragma dengan Iran Seismic Code.

\section{Klasifikasi fleksibilitas diafragma menurut FEMA 356}

Setelah dikembangkan, menurut FEMA 356 diafragma adalah kaku jika $\lambda<0.5$, diafragma fleksibel ketika $\lambda>2$, dan diafragma tidak kaku maupun tidak fleksibel (semi-kaku) ketika $0.5 \leq \lambda<2$ (Moeini M.: 2011, 27).

Gambar 1 menunjukkan perbedaan antara nilai nilai simpangan pada rumusan diatas.

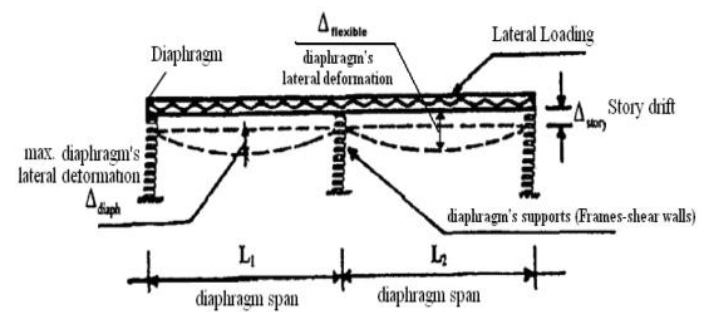

Gambar 1 Perbedaan Nilai $\Delta$ Pada Pengecekan Fleksibilitas Diafragma (Moeini M., 2011: 27)

\section{Klasifikasi fleksibilitas diafragma menurut SNI 1726:2012}

Menurut SNI 1726:2012 diafragma adalah kaku jika perandingan S/De tidak lebih dari tiga. Lalu diafragma adalah fleksibel jika defleksi diafragma maksimum (DDM) dibagi dengan simpangan rata-rata elemen vertikal (SREV) melebihi dari dua. Gambar 2 menunjukkan pengecekan fleksibilitas diafragma menurut SNI 1726:2012.

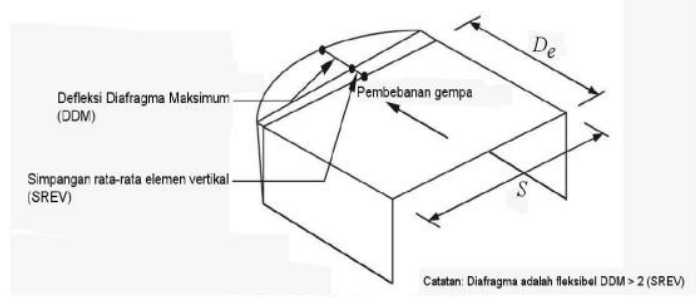

Gambar 2 Pengecekan Fleksibilitas Diafragma (SNI 1726:2012, 2012: 4) 


\section{Perilaku struktural diafragma}

\section{Model ekuivalen balok}

Metode ini mensimulasikan diafragma sebagai balok yang membentang di antara dua perletakan yang kaku. Dimana perletakan kaku itu berupa dinding geser. Diagram geser dan momen di buat seolah-olah diafragma adalah balok (Pramod A.: 2017, 127). Model ini dapat dilihat pada Gambar 3.
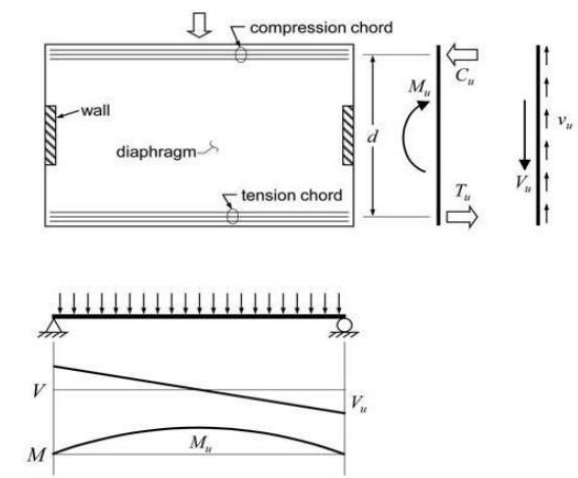

Gambar 3 Model Ekuivalen Balok (Pramod A., 2017: 127)

\section{Model ekuivalen balok dengan pegas}

Model ini mengubah perletakan kaku pada balok menjadi perletakan yang fleksibel, yaitu pegas. Hal ini cocok untuk gedung bertingkat satu dengan kekakuan pegas yang sudah ditentukan atau dapat diketahui. Diafragma dapat didekati dengan balok yang sangat kaku (rigid) atau balok yang memperhitungkan kekakuan lentur dan kekakuan geser (semi-rigid) (Pramod A.: 2017, 127). Untuk model ini dapat dilihat di Gambar 4.

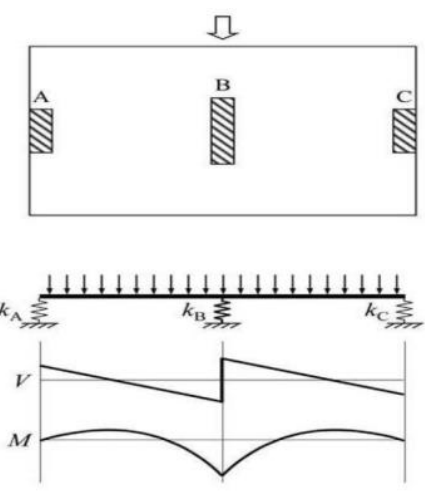

Gambar 4 Model Balok Dengan Pegas (Pramod A., 2007)

\section{Metode strut and tie}

Adanya bukaan yang besar pada diafragma akan menimbulkan masalah jika analisis diafragma yang digunakan adalah model ekuivalen balok. Metode ini dapat digunakan pada struktur yang memiliki ketidakberaturan dan dapat menjadi pendekatan alternatif untuk pemodelan diafragma sebagai balok. Para pengguna metode ini mendesain tulangan pada daerah tegangan tarik pada diafragma (Bull D.K.: 2003, 74).

Pada Gambar 5 dapat dilihat aliran gaya digambarkan seperti gaya tekan (strut) yang berubungan dengan daerah tarik pada kord atau balok. Gambar 5(a) menggambarkan perilaku ekuivalen balok seperti Gambar 3, Gambar 5(b) lebih mempresentasikan sebagai model rangka. Gambar 5(c) menunjukkan potongan dari lantai, dimana terdapat daerah tekan (strut) pada perimeter gedung atau pada daerah kolom, penulangan terhadap daerah tarik yang diikat ke bagian tertentu pada lantai, strut lokal atau shear friction di antara potongan lantai dan balok perimeter. Setiap potongan lantai bisa dimodelkan sekecil mungkin dengan strut and tie, dan akan membentuk keseluruhan solusi strut and tie untuk sepanjang lantai (Bull D.K.: 2003, 74). 


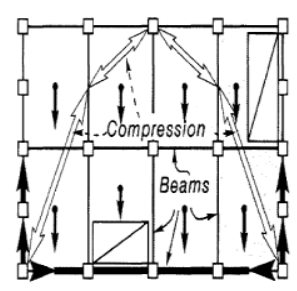

(a)

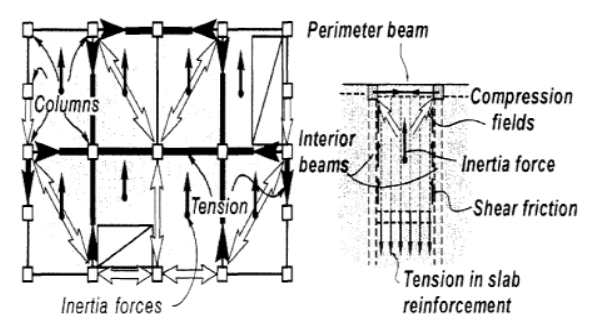

(b)

(c)

Gambar 5 Arah Gaya Metode Strut and Tie (Bull D.K., 2003: 75)

\section{Perhitungan in-plane force pada program ETABS}

Pada kajian analisis fleksibilitas diafragma ini, penulis akan fokus terhadap stiffness modifier untuk F11, F22 dan F12, maka dari itu perlu diketahui lebih lanjut bagaimana cara ETABS menghitung nilai F11, F22, dan F12 tersebut. Nilai F11, F22, dan F12 didapatkan dari integrasi persamaan tegangan terhadap variabel ketebalan lantai (CSI Analysis Reference Manual: 2016, 211). Berikut persamaannya:

$$
\begin{aligned}
& F_{11}=\int_{-\mathbf{t h} / 2}^{+ \text {th } / 2} \sigma_{11} d x_{3} \\
& F_{22}=\int_{-\mathbf{t h} / 2}^{+ \text {th } / 2} \sigma_{22} d x_{3} \\
& F_{12}=\int_{-\mathbf{t h} / 2}^{+\mathbf{t h} / 2} \sigma_{12} d x_{3}
\end{aligned}
$$

Keterangan:

- th dan x3 adalah variabel ketebalan lantai;

- $\sigma$ adalah tegangan;

- F adalah gaya sejajar bidang.

\section{Metode koreksi torsi oleh Muto}

Jika garis berat gaya geser dalam satu arah dan garis pusat gaya geser suatu tingkat tidak berhimpit, gaya geser akan menimbulkan rotasi terhadap pusat kekakuan. Bila eksentrisitas ini cukup besar, distribusi gaya geser perlu di koreksi (Muto K.: 1963, 260). Persamaan $\alpha y$ adalah faktor koreksi yang diperlukan untuk gaya geser arah y, persamaan ini berlaku pada lantai yang kaku (diafragma kaku). Koreksi ini dapat diterapkan dengan mengkalikan $\alpha$ dengan gaya geser. Persamaan 6 akan menunjukkan rumus perhitungan koreksi torsi arah y.

$$
\alpha y=1+\frac{\Sigma D y . e}{J x+J y} x
$$

Keterangan:

- $\quad \mathrm{x}, \mathrm{y}$ adalah jarak terhadap sumbu-sumbu yang melalui pusat gaya geser (m);

- Jx, Jy adalah momen inersia dari $D$-Value atau inersia polar (kNmm);

- Dy adalah $D$-value atau kekakuan setiap as arah y $(\mathrm{kN} / \mathrm{mm})$;

- $\quad \alpha y$ adalah koreksi gaya geser akibat torsi untuk arah y;

- e adalah eksentrisitas antara pusat massa dan pusat gaya geser ditambahkan lima persen dimensi tegak lurus arah gaya yang ditinjau (m).

\section{Metode koreksi torsi dengan penambahan momen kopel}

Persamaan 7 akan menunjukkan rumus untuk menghitung momen torsi pada lantai. Persamaan 8 akan menunjukkan rumus ekuivalen untuk menentukan gaya kopel, dengan asumsi satu lantai terdapat dua gaya kopel.

$$
\begin{gathered}
M z=F y e \\
F y e=F 1 e 1+F 2 e 2
\end{gathered}
$$


Keterangan:

- Mz adalah momen torsi arah sumbu $\mathrm{Z}(\mathrm{kNm})$;

- e adalah eksentrisitas tambahan sebesar 5 persen dimensi tegak lurus gaya yang di tinjau (m);

- Fy adalah gaya gempa pada lantai yang ditinjau $(\mathrm{kN})$;

-F1 dan F2 adalah gaya kopel yang ditentukan $(\mathrm{kN})$;

- e1 dan e2 adalah jarak antara gaya-gaya kopel (m).

Gambar 6 akan menunjukkan contoh aplikasi metode gaya kopel dalam kajian ini.

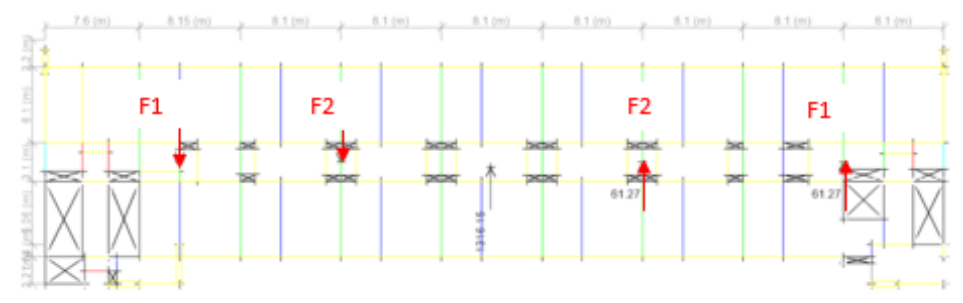

Gambar 6 Penerapan Metode Momen Kopel

\section{SIMULASI MODEL}

\section{Model}

\section{Material struktur}

Material struktur yang digunakan adalah beton bertulang, dengan kuat tekan karakteristik, f'c = 40 MPa. Tulangan lentur dan tulangan geser menggunakan tulangan ulir dengan fy $=400 \mathrm{MPa}$.

\section{Dimensi komponen struktur}

Terdapat tujuh ukuran balok pada setiap lantai yakni, $250 \mathrm{~mm}$ x $350 \mathrm{~mm}, 250 \mathrm{~mm}$ x $400 \mathrm{~mm}, 300 \mathrm{~mm}$ x $400 \mathrm{~mm}$, $300 \mathrm{~mm}$ x $500 \mathrm{~mm}, 350 \mathrm{~mm}$ x $500 \mathrm{~mm}, 400 \mathrm{~mm}$ x $500 \mathrm{~mm}$, dan $400 \mathrm{~mm}$ x $700 \mathrm{~mm}$. Efektivitas penampang diberikan faktor 0.35 ketika balok dianggap mengalami keretakan (crack) berdasarkan SNI 2847:2013 Pasal 10.10.4.1

Pelat lantai terdiri dari ketebalan $120 \mathrm{~mm}, 130 \mathrm{~mm}$, dan $150 \mathrm{~mm}$. Untuk diafragma lantai dimodelkan pada setiap lantai secara identik, dengan memberikan garis-garis perpanjangan diafragma pada setiap joint ke pusat massa lantai. Diafragma untuk analisis statik dan dinamik awalnya diasumsikan sebagai Rigid, lalu untuk analisis yang menggunakan variasi kekakuan diafragma, diafragma akan dimodelkan sebagai Semi-Rigid. Penggambaran diafragma lantai dapat dilihat di Gambar 7.

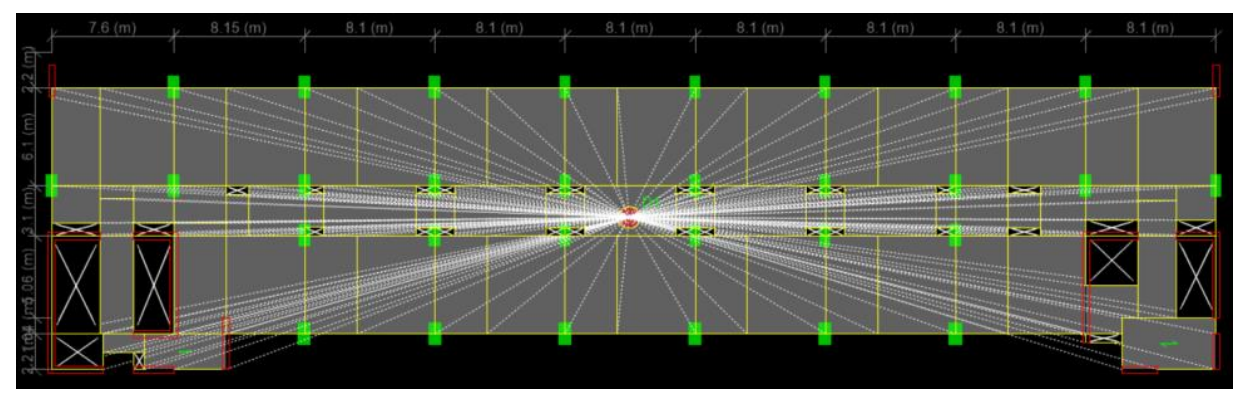

Gambar 7 Diafragma Rigid dan Diafragma Semi-Rigid

Kolom direncanakan dengan ukuran $700 \mathrm{~mm}$ x $1400 \mathrm{~mm}$ dan $800 \mathrm{~mm}$ x $1400 \mathrm{~mm}$. Efektivitas penampang diberikan faktor 0.7 ketika kolom dianggap mengalami crack berdasarkan SNI 2847:2013 Pasal 10.10.4.1.

Dinding geser dimodelkan sebagai shell element, dengan dimensi ketebalan $400 \mathrm{~mm}$ dan $450 \mathrm{~mm}$. Lalu diberi faktor reduksi sebesar 0.7 berdasarkan SNI 2847:2013 Pasal 10.10.4.1. 


\section{Pembebanan}

Beban mati terdiri dari berat sendiri beton yakni $2.4 \mathrm{kN} / \mathrm{m}^{3}$ dan beban mati tambahan berupa penutup lantai, ducting, plafon, spesi dan mekanikal elektrikal. Dimana total keseluruhan beban mati tambahan sebsar $1.2 \mathrm{kN} / \mathrm{m}^{2}$. Beban partisi atau dinding menggunakan Hebel Blockwork sebesar $2.625 \mathrm{kN} / \mathrm{m}$.

Beban gempa terdiri dari beban gempa statik dan beban gempa dinamik. Untuk input beban gempa dinamik, digunakan opsi Load Cases dengan Load Case Type adalah Response Spectrum. Lalu Load Type adalah Acceleration sesuai arah X dan arah Y yaitu dalam opsi ETABS disebut U1 dan U2. Dan beban diberi faktor skala sebesar Ie/R sesuai SNI 1726:2012 Pasal 7.9.2. Karena nilai I pada struktur ini adalah satu dan nilai R pada struktur ini adalah tujuh berdasarkan subbab 3.4.3 maka nilai faktor skala adalah 1400.95 (gravitasi dibagi dengan tujuh).

4. Tampak tiga dimensi struktur

Tampak tiga dimensi struktur dapat dilihat pada Gambar 8.

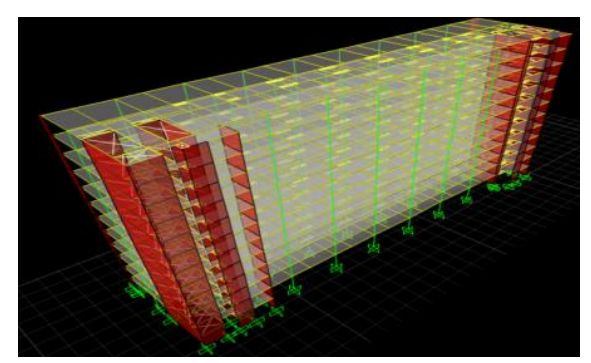

Gambar 8 Tampak Tiga Dimensi Struktur

\section{Parameter gempa}

Struktur mempunyai nilai S1 < 0.75 maka struktur tersebut bukan termasuk Kategori Desain Seismik (KDS) E. Struktur berdasarkan hitungan ETABS memiliki nilai SDS sebesar 0.6075 dan SD1 sebesar 0.298, maka berdasarkan SNI 1726:2012 Tabel 6 dan Tabel 7, struktur termasuk Kategori Desain Seismik D. Dari detail struktur didapatkan struktur penahan gempa pada bangunan tersebut menggunakan sistem ganda, berdasarkan Tabel 9 (SNI 1726:2012 hal 34) maka nilai:

- koefisien modifikasi respons, $\mathrm{Ra}=7$;

- faktor kuat lebih sistem, $\Omega 0=2,5$;

- faktor pembesaran defleksi, $\mathrm{Cd}=5,5$;

- batasan sistem struktur dan batasan tinggi struktur tidak dibatasi.

\section{Prosedur analisis}

Prosedur analisis di gambarkan melalui Gambar 9.
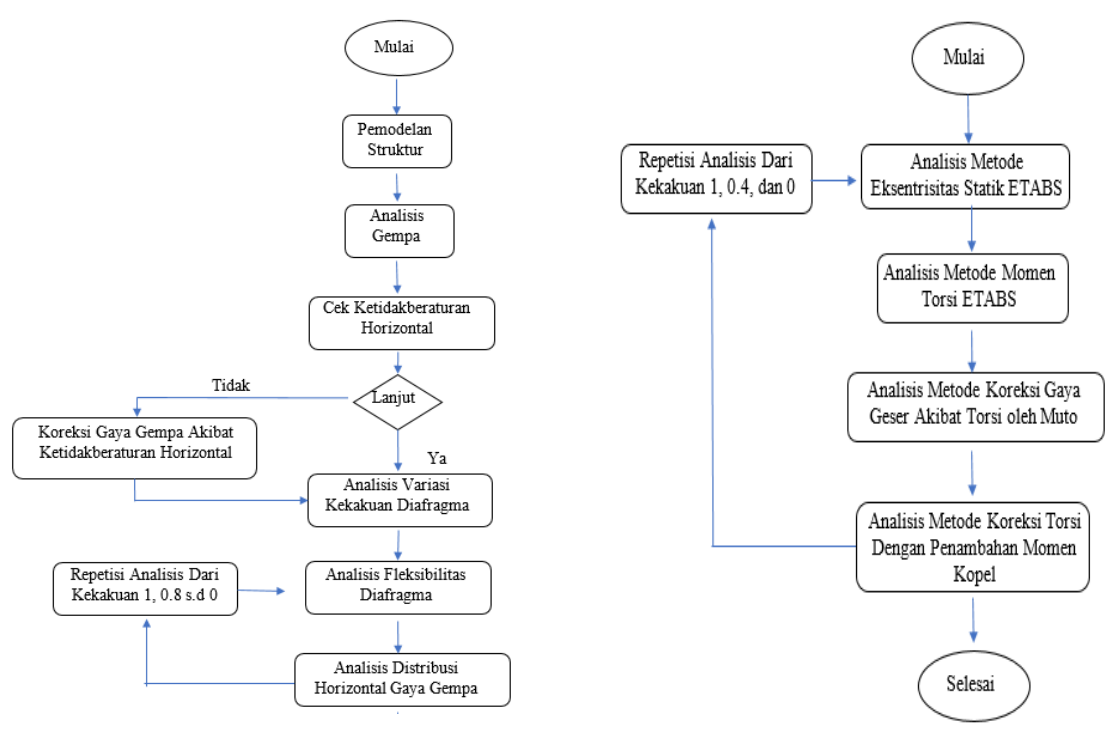

Gambar 9 Prosedur Analisis Pengaruh Fleksibilitas Diafragma terhadap Distribusi Horizontal Gaya Gempa 


\section{HASIL DAN PEMBAHASAN}

\section{Klasifikasi fleksibilitas diafragma}

Tabel 1 menunjukkan klasifikasi fleksibilitas diafragma menurut UBC 1997 dan SNI 1726:2012, Tabel 2 menunjukkan klasifikasi fleksibilitas diafragma menurut FEMA 356, dan Tabel 3 menunjukkan kesimpulan hasil dari perhitungan klasifikasi fleksibilitas diafragma.

Tabel 1 Klasifikasi Diafragma menurut UBC 1997 dan SNI 1726:2012

Tabel 2 Klasifikasi Diafragma menurut FEMA 356

\begin{tabular}{|c|c|c|c|c|c|c|}
\hline \multirow{2}{*}{ Story } & \multicolumn{6}{|c|}{ Klasifikasi Diafragma } \\
\cline { 2 - 7 } & \multicolumn{6}{|c|}{ Modifier Kekakuan Diafragma } \\
\cline { 2 - 7 } & 1 & 0.8 & 0.6 & 0.4 & 0.2 & 0 \\
\hline 12 & Fleksibel & Fleksibel & Fleksibel & Fleksibel & Fleksibel & Fleksibel \\
\hline 11 & Kaku & Fleksibel & Fleksibel & Fleksibel & Fleksibel & Fleksibel \\
\hline 10 & Kaku & Fleksibel & Fleksibel & Fleksibel & Fleksibel & Fleksibel \\
\hline 9 & Kaku & Kaku & Fleksibel & Fleksibel & Fleksibel & Fleksibel \\
\hline 8 & Kaku & Kaku & Kaku & Fleksibel & Fleksibel & Fleksibel \\
\hline 7 & Kaku & Kaku & Kaku & Kaku & Fleksibel & Fleksibel \\
\hline 6 & Kaku & Kaku & Kaku & Kaku & Kaku & Fleksibel \\
\hline 5 & Kaku & Kaku & Kaku & Kaku & Kaku & Fleksibel \\
\hline 4 & Kaku & Kaku & Kaku & Kaku & Kaku & Fleksibel \\
\hline 3 & Kaku & Kaku & Kaku & Kaku & Kaku & Kaku \\
\hline 2 & Kaku & Kaku & Kaku & Kaku & Kaku & Kaku \\
\hline 1 & Kaku & Kaku & Kaku & Kaku & Kaku & Kaku \\
\hline
\end{tabular}

\begin{tabular}{|c|c|c|c|c|c|c|}
\hline \multirow{3}{*}{ Story } & \multicolumn{7}{|c|}{ Klasifikasi Diafragma } \\
\cline { 2 - 7 } & \multicolumn{7}{|c|}{ Modifier Kekahuan Diafragma } \\
\cline { 2 - 7 } & 1 & 0.8 & 0.6 & 0.4 & 0.2 & 0 \\
\hline 12 & Fleksibel & Fleksibel & Fleksibel & Fleksibel & Fleksibel & Fleksibel \\
\hline 11 & Semi-Kaku & Fleksibel & Fleksibel & Fleksibel & Fleksibel & Fleksibel \\
\hline 10 & Semi-Kaku & Fleksibel & Fleksibel & Fleksibel & Fleksibel & Fleksibel \\
\hline 9 & Semi-Kaku & Semi-Kaku & Fleksibel & Fleksibel & Fleksibel & Fleksibel \\
\hline 8 & Semi-Kaku & Semi-Kaku & Semi-Kaku & Fleksibel & Fleksibel & Fleksibel \\
\hline 7 & Semi-Kaku & Semi-Kaku & Semi-Kaku & Semi-Kaku & Fleksibel & Fleksibel \\
\hline 6 & Semi-Kaku & Semi-Kaku & Semi-Kaku & Semi-Kaku & Semi-Kaku & Fleksibel \\
\hline 5 & Semi-Kaku & Semi-Kaku & Semi-Kaku & Semi-Kaku & Semi-Kaku & Fleksibel \\
\hline 4 & Semi-Kaku & Semi-Kaku & Semi-Kaku & Semi-Kaku & Semi-Kaku & Fleksibel \\
\hline 3 & Semi-Kaku & Semi-Kaku & Semi-Kaku & Semi-Kaku & Semi-Kaku & Semi-Kaku \\
\hline 2 & Kaku & Semi-Kaku & Semi-Kaku & Semi-Kaku & Semi-Kaku & Semi-Kaku \\
\hline 1 & Kaku & Kaku & Kaku & Kaku & Semi-Kaku & Semi-Kaku \\
\hline
\end{tabular}

Tabel 3 Kesimpulan Hasil Perhitungan Klasifikasi Fleksibilitas Diafragma

\begin{tabular}{|c|c|c|c|c|c|c|}
\hline \multirow{2}{*}{ Code } & \multicolumn{7}{|c|}{ Modifier Kekakuan Diafragma } \\
\cline { 2 - 7 } & 1 & 0.8 & 0.6 & 0.4 & 0.2 & 0 \\
\hline UBC 1997 & Kaku & Kaku & Kaku & Kaku & Fleksibel & Fleksibel \\
\hline FEMA 356 & Semi-Kaku & Semi-Kaku & Semi-Kaku & Semi-Kaku & Fleksibel & Fleksibel \\
\hline SNI 1726:2012 & Kaku & Kaku & Kaku & Kaku & Fleksibel & Fleksibel \\
\hline
\end{tabular}

Dari hasil perhitungan klasifikasi fleksibilitas diafragma, dapat dilihat bahwa berdasarkan UBC 1997 dan SNI 1726:2012 (Tabel 1), diafragma memiliki klasifikasi yang sama. Dimana untuk modifier kekakuan diafragma diatas 0.4, lantai-lantai teratas mempunyai klasifikasi diafragma fleksibel dan lantai-lantai terbawah memiliki klasifikasi diafragma kaku. Diafragma struktur mulai dominan fleksibel ketika modifier kekakuannya kurang dari 0.2.

Dari perhitungan klasifikasi diafragma berdasarkan FEMA 356 (Tabel 2), dapat dilihat bahwa klasifikasi diafragma struktur didominasi oleh klasifikasi diafragma semi-kaku. Dimana untuk modifier kekakuan diafragma diatas 0.4, lantai-lantai teratas mempunyai klasifikasi diafragma fleksibel sedangkan lantai-lantai terbawah memiliki klasifikasi diafragma kaku. Untuk lantai-lantai tengah seperti lantai 2 sampai dengan lantai 7 memiliki klasifikasi diafragma semi-kaku. Diafragma struktur mulai dominan fleksibel ketika modifier kekakuannya kurang dari 0.2.

\section{Pengaruh fleksibilitas diafragma terhadap distribusi horizontal gaya gempa}

Hasil dari analisis ini akan ditunjukkan melalui grafik distribusi horizontal lantai 1 dan lantai 12 pada Gambar 10.

Pengaruh fleksibilitas diafragma terhadap distribusi horizontal dapat diketahui melalui grafik distribusi horizontal gaya gempa pada Gambar 10. Dimana untuk lantai 1 ketika kekakuan diafragma semakin besar maka gaya gempa akan terdistribusi pada as yang memiliki kekakuan elemen vertikal yang besar, yaitu as yang memiliki dinding geser. Lalu ketika kekakuan diafragma semakin kecil, diafragma akan sulit mendistribusi gaya gempa ke elemen verikal yang kaku, sehingga as yang hanya memiliki portal rangka atau kolom akan mengalami peningkatan distribusi horizontal gaya gempa. Untuk lantai 12, karena diafragma sudah fleksibel ketika modifier kekakuannya 1, maka akan terjadi ketidakberaturan distribusi horizontal gaya gempa. Selain itu, letak dinding geser yang tidak simetris juga mempengaruhi ketidakberaturan pada distribusi horizontal gaya gempa pada lantai 12 . 

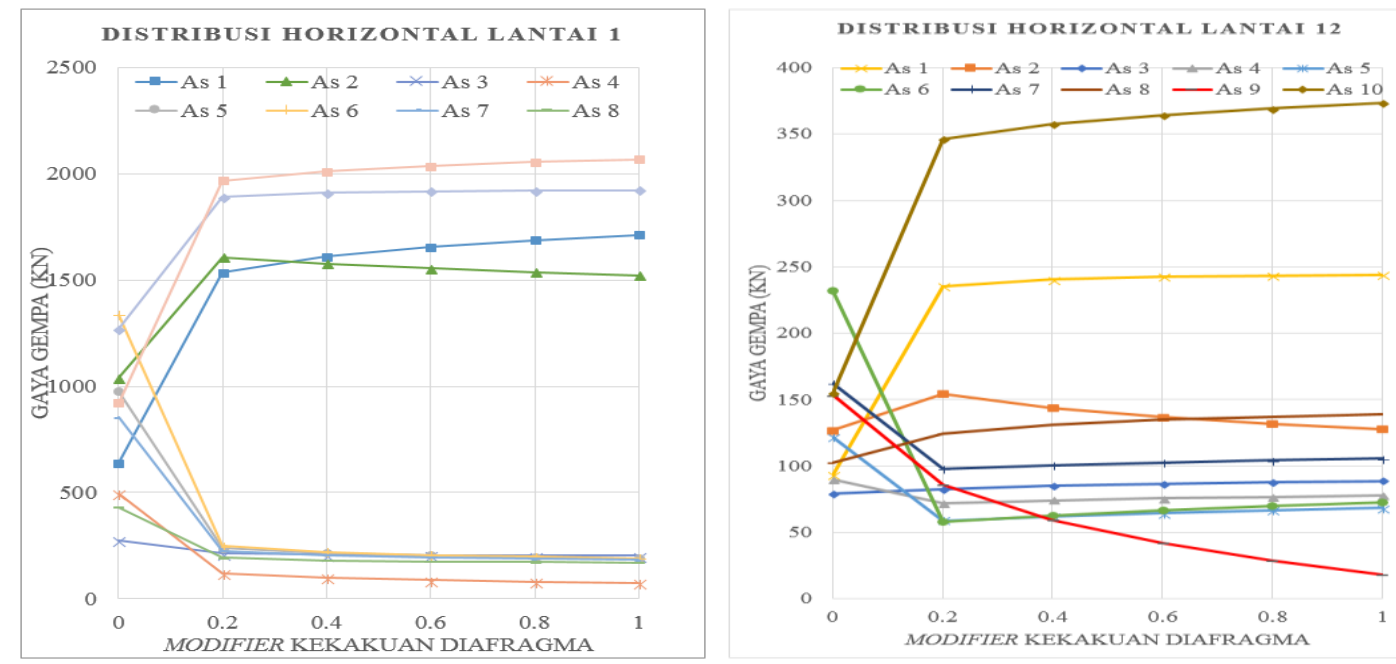

Gambar 10 Grafik Distribusi Horizontal Gaya Gempa pada Lantai 1 dan Lantai 12

\section{Metode koreksi torsi pada diafragma semi-kaku}

Hasil dari analisis ini ditunjukkan melalui grafik perbedaan koreksi gaya geser akibat torsi di lantai 1 pada Gambar 11 dan grafik perbedaan koreksi gaya geser akibat torsi di lantai 12 pada Gambar 12.
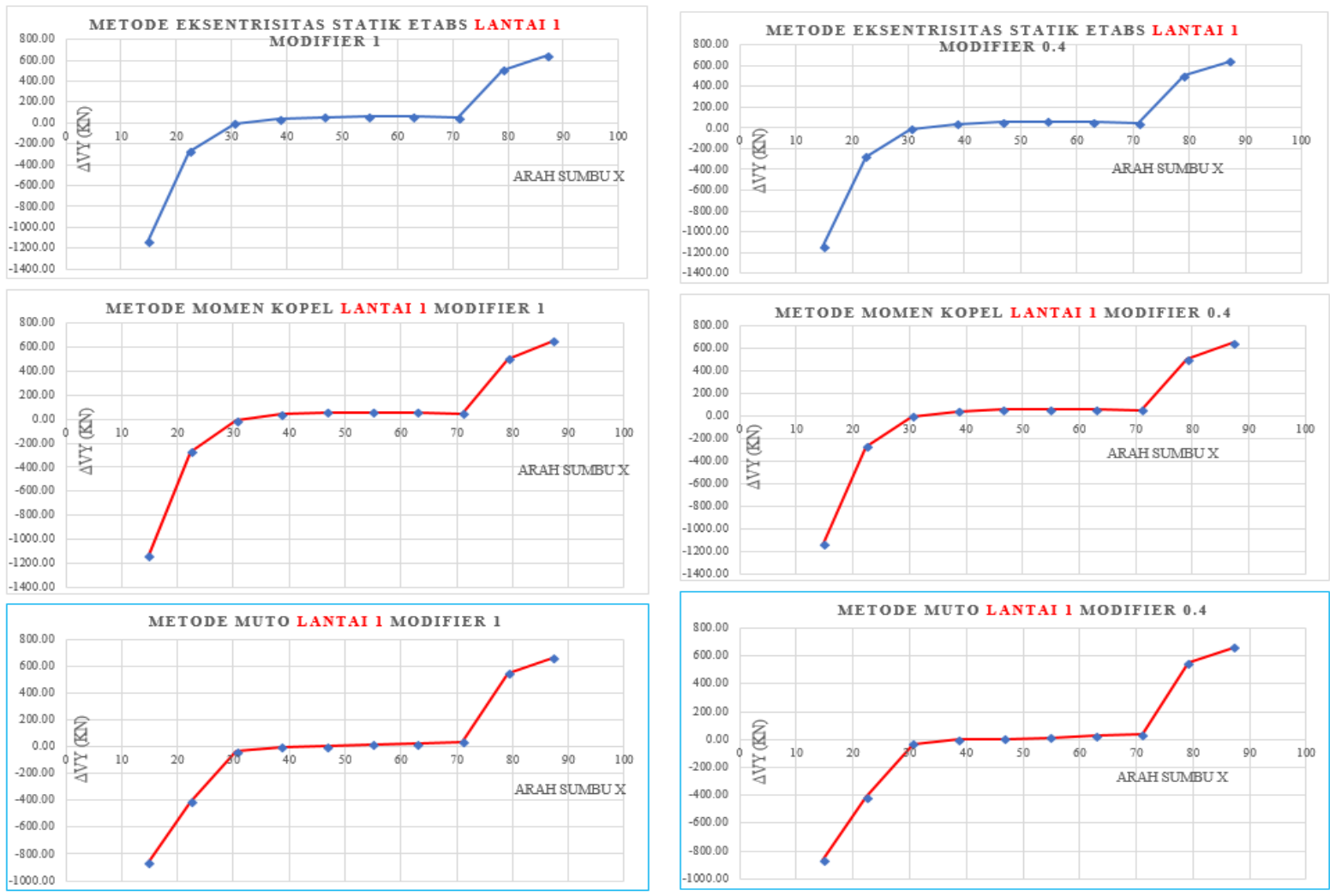

Gambar 11 Grafik Perbedaan Koreksi Gaya Geser akibat Torsi pada Lantai 1 

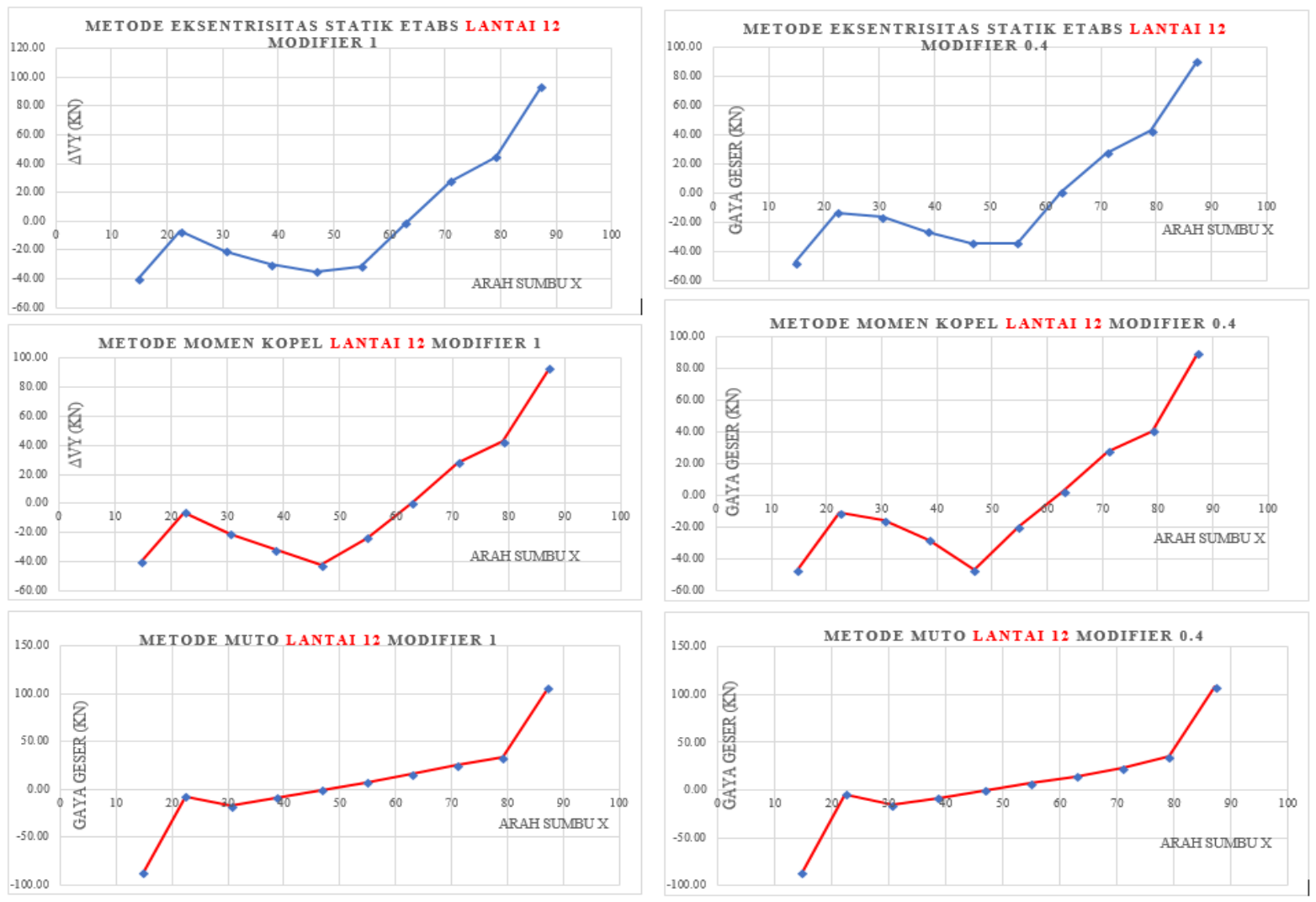

Gambar 12 Grafik Perbedaan Koreksi Gaya Geser akibat Torsi pada Lantai 12

Dari Gambar 11 dan Gambar 12, dapat dilihat bahwa koreksi torsi dengan metode momen kopel memiliki perbedaan yang kecil dengan metode ETABS. Koreksi torsi dengan metode Muto memiliki perbedaan yang jauh dengan metode ETABS ataupun metode momen kopel.

\section{KESIMPULAN}

1. Klasifikasi fleksibilitas diafragma berdasarkan UBC 1997 dan SNI 1726:2012, mempunyai hasil klasifikasi yang sama pada setiap lantai dan pada setiap modifier kekakuan diafragma. Sedangkan klasifikasi diafragma menurut FEMA 356 berbeda dengan klasifikasi diafragma pada UBC 1997 dan SNI 1726:2012 pada lantai-lantai yang lebih rendah.

2. Diafragma pada contoh gedung diklasifikasikan sebagai diafragma kaku jika modifier kekakuan diafragma lebih dari 0.2 dan diklasifikasikan sebagai diafragma fleksibel jika modifier kekakuan diafragma kurang dari atau sama dengan 0.2 berdasarkan UBC 1997 dan SNI 1726:2012. Dan berdasarkan FEMA 356, diafragma diklasifikasikan semi-kaku jika modifier kekakuan diafragma lebih dari 0.2 dan diklasifikasikan fleksibel jika modifier kekakuan diafragma kurang dari atau sama dengan 0.2.

3. Distribusi horizontal gaya gempa pada lantai 12 akan memiliki perilaku yang berbeda dengan lantai-lantai dibawahnya, dikarenakan lantai 12 adalah lantai yang fleksibel berdasarkan UBC 1997, FEMA 356, dan SNI 1726:2012.

4. Gaya gempa terdistribusi ke dinding geser jika digunakan modifier kekakuan diafragma di atas 0.2, sedangkan sulit terdistribusi ke dinding geser jika digunakan modifier kekakuan diafragma dibawah 0.2. Hal ini bisa dijadikan pertimbangan jika melakukan reduksi kekakuan sejajar bidang diafragma sesuai dengan referensi ETABS, yakni 0.25. Dimana jika kekakuan diafragma direduksi sebesar 0.25, maka dinding geser akan lebih sedikit memikul gaya gempa dibandingkan tanpa reduksi kekakuan sejajar bidang diafragma (modifier sebesar satu).

5. Metode koreksi gaya geser akibat torsi oleh Muto tidak tepat jika diterapkan pada diafragma semi-kaku. Hal ini ditunjukkan dengan perbedaan yang besar antara grafik metode eksentrisitas statik ETABS dan grafik metode koreksi gaya geser akibat torsi oleh Muto.

6. Metode koreksi gaya geser dengan penambahan momen kopel yang diterapkan pada kajian ini memiliki perbedaan yang kecil dengan metode eksentrisitas statik ETABS pada modifier kekakuan diafragma 1 dan 0.4. 
Dimana terdapat banyak persamaan Distribusi Horizontal Gaya Geser pada berberapa letak as atau dinding geser yang ditinjau.

7.Untuk diafragma semi-kaku, pengaruhnya terhadap distribusi horizontal gaya gempa adalah jika modifier kekakuan diafragma semakin besar, maka gaya gempa akan cenderung terdistribusi pada elemen vertikal yang lebih kaku, jika modifier kekakuan diafragma semakin kecil, maka gaya gempa akan cenderung terdistribusi pada elemen vertikal yang lebih fleksibel. Hal ini juga ditentukan oleh penerapan metode koreksi torsi pada diafragma semi-kaku yang tepat, yakni metode eksentrisitas statik ETABS, metode momen torsi ETABS, dan metode koreksi torsi dengan penambahan momen kopel.

8. Untuk diafragma fleksibel (modifier kekakuan diafragma nol), distribusi horizontal gaya gempa tidak memperhatikan kekakuan relatif antara elemen vertikal dan elemen horizontal karena kekakuan horizontalnya nol. Sehingga gaya gempa akan terbagi sesuai dengan tributari massa dari masing-masing elemen vertikal

\section{DAFTAR PUSTAKA}

Abera, S. Effects of Floor Diaphragm Flexibility in Reinforced Concrete Structures and Code Provision. Thesis, Addis Ababa, 2015.

BHRC. Iranian Code of Practice For Seimic Resistant Design of Buildings 3rd Edition. Tehran: BHRC Publication, 2007.

BSN. Persyaratan Beton Struktural untuk Bangunan Gedung (SNI 2847:2013). Jakarta: BSN, 2013.

BSN. Standar Perencanaan Ketahanan Gempa untuk Struktur Bangunan Gedung (SNI 03-1726-2002). Jakarta: BSN, 2002.

BSN. Tata Cara Perencanaan Ketahanan Gempa Untuk Bangunan Gedung dan Non Gedung (SNI 1726:2012). Jakarta: BSN, 2012.

Bull, D.K. Understanding The Complexities of Designing Diaphragms in Builidng for Earthquakes. (2003).

CSI. Analysis Reference Manual. California: Computer and Structures Inc, 2016.

FEMA. NEHRP Guidlines For The Seismic Rehabilitation fot New Buildings and Other Structures (FEMA 451B). California: Federal Emergency Management Agency, 2007.

FEMA. NEHRP Guidlines For The Seismic Rehabilitation of Buildings (FEMA 356). California: Federal Emergency Management Agency, 1997.

Goel, K dan Chopra, K. Seismic Code Analysis of Buildings Wihout Locating Centers of Rigidity. ASCE Journal Of Structural Engineering (1999).

ICBO. Uniform Building Code. California: International Conference of Building Officials, 1997.

Moeini, M dan Rafehzi, B. Investigation Into The Floor Diaphragms Flexibility in Reinforced Concrete Structures and Code Provision. Global Journal of Researches in Engineering (2011).

Muto, K. Seismic Analysis Of Reinforced Concrete Buildings. Tokyo: Marunzen Co. Ltd., 1974.

Nguyen, D. A Brief Study of Using Membrane, Shell or Plate in Assigning a Slab or Wall. Tersedia di www: https://www.slideshare.net/neikrof/membrane-plate-shell. (3 September 2010).

Pramod, A, Karale, S, dan Ansari, U. Analysis of Floor Diaphragm in Multi Storied Reinforced Concrete Building Reinforced Concrete Building. International Advanced Research Journal in Science (2007). 